\title{
Quality Control of Mass Rearing of Egg Parasitoids of Yellow Rice Stem Borer Scirpophaga incertulas Walker
}

\author{
Wilyus $^{\#}$, Fuad Nurdiansyah", Siti Herlinda ${ }^{*}$, Chandra Irsan$^{*}$, Yulia Pujiastuti* \\ \# Plant Protection, Jambi University, Mandalo Indah, Jambi, 36361, Indonesia \\ E-mail:wilyus@unja.ac.id
}

*Plant Protection, Sriwijaya University, Palembang, Indonesia

E-mail: sitiherlinda@unsri.ac.id

\begin{abstract}
The study was conducted to find out: suitability of eggs of Corcyra cephlalonica Stainton as a factitious host of $S$. incertulas egg parasitoids and techniques of parasitoid stock provision, serially conducted from February 2011 to December 2011 . The researches were carried out in four laboratory experiments, consisting of the study of ultraviolet (UV) irradiation on $C$. cephalonica eggs; suitability of $\mathrm{C}$. cephlalonica eggs as a factitious host of Telenomus rowani Gahan, Trichogramma japonicum Ashmead and Tetrastichus schoenobii Ferriere; storage method of $C$. cephalonica eggs; and storage method of parasitoids. The research design was suited to the research needs. The results showed that; The $C$. cephalonica eggs irradiated by the minimum of 28.48 minute 15 watt ultraviolet (UV) at a distance $+15 \mathrm{~cm}$ between the lamp and the eggs could suppress the hatching eggs to zero (no emerged larvae). Among the three species of egg parasitoids of $S$. incertulas found in Jambi Province, only $T$. japonicum could be rearing on $C$. cephalonica eggs. The relationship between storage duration of $C$. cephalonica eggs irradiated by the 30 minutes 15 watts $\mathrm{UV}$ at $50 \mathrm{C}$ and the emerged $T$. japonicum wasps was expressed by the equation of $y=31.04-1.151 x, R^{2}=0.865, P=0.000$. The storage of $T$. japonicum pupae for six weeks at $5^{\circ} \mathrm{C}$ did not reduce the number of emerged $T$. japonicum wasps. The emerged wasps reduced significantly if the storage duration of $T$. japonicum pupae was increased to seven weeks or more.
\end{abstract}

Keywords- Quality Control; Egg Parasitoid; S. incertulas; Factitious Host; C. Cepalonica.

\section{INTRODUCTION}

Rice stem borer (RSB) is the most important pests in rice [1]. Scirpophaga incertulas Walker is the most important RSB spesies throughout the world [2], [3]. There are three species of RSB eggs parasitoid that important in RSB controling. These species were Tetrastichus schoenobii Ferriere, Telenomus rowani Gahan and Trichogramma japonicum Ashmead [4], [5], [6], [7], [8], [9], [10], [11]. The ability of parasitoids to control RSB was very depend on its species [4].

Trichogramma has been researched extensively and used successfully in biological control programs and could be reproduced on factitious host [12]. A large number of parasitoid is needed in order to apply inundative control. Therefore, suitable factitious host is needed and should be available for rearing the parasitoids. Reference [13], [14] shows that Ephistia kuhniella Zell, Sitotroga cerealella and Corcyra cephalonica Stainton could be factitious host of Trichogramma spp.

Otherwise, until now there is no information about the insect that can be used as a factitious hosts of $T$. rowani and
T. schoenobii. Reference [15] shows that T. schoenobii could only be reared in eggs of Scirpophaga. The effort of in vitro rearing of parasitoid as in [16] leads the use of $T$. schoenobii in biological control. Mass production of Trichogramma spp. by using $C$. cephalonica eggs as factitious host has been carried out successfully [17], [18], [19], [20]. Reference [18] shows that C. cephalonica could be propagated easily and its eggs were very suitable as a factitious host for growing and development of Trichogramma spp. Mass production of C. cephalonica was conducted successfully [21], [22].

Stock supplying of $C$. cephalonica eggs as a factitious hosts encountere frequently obstacles due to hatch quickly and damaged easily. Reference [23] shows that $C$. cephalonica eggs irradiated by 15 watts ultraviolet lamp for 30 minutes could be sterile (unhatchable). Before being used as a factitous host, $C$. cephalonica eggs need to be irradiated by 15 watts UV for 60 minute [24], but reference [25] shows that $C$. cephalonica eggs need to be irradiated by 15 watts ultraviolet lamp for 15 minute.

It should be understood that the effectiveness of UV irradiation to sterile $C$. cephalonica eggs depend on the 
irradiation boxes specification (cabinets) used, and the irradiation duration. After parasitoids can be produced massively, the important thing should be considered is how to package and store parasitoids in a long time so the stock always available when it is needed.

The supporting information about mass production and supplying of parasitoid stock is very limited. Therefore the research was carried out. The purpose of the research were to know the suitability of $C$. cephlalonica eggs as a factitious host of $S$. incertulas egg parasitoids and to know the techniques for supplying parasitoid stock sustainability.

\section{MATERIAls AND Methods}

The experiment was conducted at the Plant Protection Laboratory of Agriculture Faculty of Jambi University from February 2011 to December 2011.

\section{A. Study of Ultraviolet Irradiation on Corcyra cephalonica eggs}

Provision of $C$. Cephalonica eggs was carried out based on the technique performed as in [18], [19], [23], [26], [22]. C. Cephalonica Eggs were glued by arabic gum glue on pias paper. The number of eggs glued were 100 eggs per pias, and then put into 15 watt UV treatment box. The distance between UV lamp and eggs is $\pm 15 \mathrm{~cm}$.

The treatments were the UV irradiation durations on $C$. Cephalonica Eggs consisting of 15, 30, 45, 60, 75, 90 minutes and control (without UV irradiation). Each treatment was repeated five times. After treatment, each replicate was inserted into a test tube and covered with tulle fabric and observed for 10 days. During the observations the number of hatched eggs (number emerged larvae), the number of unhatched eggs were recorded, and then the percentage of both hatched eggs and unhatched eggs were calculated. Data were analyzed using simple linear regression.

\section{B. The Study of Suitability of Corcyra cephalonica Eggs for Rearing of Telenomus rowani, Trichogramma japonicum and Tetrastichus schoenobii}

Provision of T. rowani, T. japonicum and T. schoenobii was done through parasitoid feeding by using $S$. incertulas eggs from rice agroecosystem in Muaro Jambi Districk of Jambi Province. Moths of $S$. incertulas were captured from the field (vegetative phase paddy) and maintained individually by using plastic bottles with diameter of $3.5 \mathrm{~cm}$ and height of $5 \mathrm{~cm}$. Pieces of fresh rice leaves inserted into the bottle for moths laying eggs. The resulted eggs were taken every day by cutting the leaf wherea the eggs attached along $\pm 4 \mathrm{~cm}$ by using scissors.

The one day old $S$. incertulas egg groups was glued on the leaves of paddy crops by a stapler. Clumps of the paddy were marked by plastic rope. After two days the eggs were taken back (harvested) by using scissor and inserted separately into test tubes and labeled. S. incertulas eggs collected were maintained at $\pm 25{ }^{\circ} \mathrm{C}$ in Plant pProtection Laboratory. During maintenance the egg groups was observed every day for 12 days. Emerged parasitoids were identified and separated according to species.

Provision of $C$. Cephalonica eggs was carried out based on the technique performed as in [18], [19], [23], [21], [22].
50 grains of $C$. cephalonica eggs were glued on $2 \times 8 \mathrm{~cm}$ pias paper. The pias paper was inserted into a test tube with diameter $2.5 \mathrm{~cm}$ and height $20 \mathrm{~cm}$. A pair of one day old $T$. rowani wasps was invested into the test tube. The Test tube was covered by tulle fabric and incubated for 12 days. The same treatments were also carried out for T. japonicum and T. schoenobii. Each treatment was repeated five times.

During the incubation period, all experimental units were observed daily and the number of parasitized $C$. cephalonica eggs, the number of both male and female of emerged parasitoid wasps were recorded, and the sex ratio of male and female was calculated. The data obtained was presented in tabular form and analyzed descriptively.

\section{Study of Storage of Corcyra cephalonica Eggs}

The treatments were the storage durations of Corcyra cephalonica Eggs, consisting of 1, 2, 3, 4, 5, 6, 7, 8, 9 weeks C. cephalonica Eggs storage duration at in the refrigerator at $\pm 5{ }^{\circ} \mathrm{C}$ and control (no-storage treatment). Each treatment including control was repeated five times. and each replicate consisting of 50 Corcyra cephalonica Eggs.

The $C$. cephalonica eggs and $T$. japonicum wasps were needed for this study. Provision of $C$. cephalonica eggs and $T$. japonicum wasps were based on the technique performed as in [19]. Before being treated, the one day old $C$. cephalonica eggs were irradiated by15 watts UV for 30 minutes. Storage duration treatments were done gradually every week, starting at 9 week storage duration treatment . Following that, the treatments of $8,7,6,5,4,3,2,1$ week storage duration treatment and control (without storage) were done consecutively.

50 C. chepalonica eggs of each treatment were glued on $2 \times 8 \mathrm{~cm}$ paper pias and put into a test tube that its diameter $2.5 \mathrm{~cm}$, height $20 \mathrm{~cm}$. Into the test tube was invested a pair of one day old $T$. japonicum wasps. The $T$. japonicum wasps used were the results of multiplication in the laboratory. The test tubes were covered with tulle fabric and incubated for 12 days. Each treatment was repeated five times.

Each experimental unit was observed each day for 12 days. During observations the number of parasitized $C$. cephalonica eggs and emerged $T$. japonicum wasps were noted. The data obtained were analyzed using simple linear regression.

\section{Study of Storage of Parasitoid}

Completely randomized design was used in this study. The treatments were the storage durations of $T$. japonicum pupae, consisting of $1,2,3,4,5,6,7,8,9$ weeks $T$. japonicum pupae storage duration in the refrigerator at a temperature of $5{ }^{\circ} \mathrm{C}$ and control (no-storage treatment). Each treatment including control was repeated five times and each replicate consisting of $\pm 100 T$. japonicum pupae.

$T$. japonicum pupae was obtained with the modified parasitoids propagation method as in [19], [20]. On pias paper was made 50 circular form template that its diameter $6 \mathrm{~mm}$ by paper puncher. One day old C. cephalonica eggs irradiated by 15 watts UV for 30 minutes were glued on those 50 template of pias paper by arabic gum glue. 
The pias paper that had 50 egg groups of C. cephalonica was inserted into a test tube that its diameter of $2.5 \mathrm{~cm}$ and height of $20 \mathrm{~cm}$ which already contains a pias of one day old $T$. japonicum wasps (about 2,000 $T$. japonicum wasps). Color of $C$. chephalonica eggs parasitized by $T$. japonicum changed to be black in 3-4 days after being invested by $T$. japonicum wasps, and become pupae at 6 day after invested.

The $T$. japonicum pupae ( 6 days old parassitoid pias) were excluded from the test tube and treated by storage duration, consisting of $1,2,3,4,5,6,7,8,9$ weeks pupae storage duration in the refrigerator at $\pm 5{ }^{\circ} \mathrm{C}$ and control (no-treatment of storage pupae). Each treatment including control was repeated five times and each replicate consisting of 1 group of $T$. japonicum pupae $( \pm 100 \mathrm{~T}$. japonicum pupae).

After storage treatment, parasitoid pias was removed from the freezer and placed in a room at $\pm 25^{\circ} \mathrm{C}$. Observation were made to see the emergence of $T$. japonicum wasps. Observation was made after all appeared parasitoid wasps were dead. In observation the number of pupae treated, the number both male and female emerged parasitoid wasps were recorded. Then the proportion of emerged parasitoid wasps and the sex ratio of male and female were calculated. Data were analyzed by analysis of variance and Duncan multiple rang test at the level of $\alpha=0.05$.

\section{RESULTS AND DISCUSSION}

\section{A. Ultraviolet Irradiation on Corcyra cephalonica Eggs}

The relationship between the 15 watt ultraviolet radiation at a distance of light and eggs $+15 \mathrm{~cm}$ and hatching of $\mathrm{C}$. cephalonica eggs was expressed by the equation of $\mathrm{y}=81.26-2.853 \mathrm{x}, \mathrm{R}=0.963, \mathrm{R}^{2}=0.927, \mathrm{P}=0.000$, where $\mathrm{y}=$ the number of hatched $\mathrm{C}$. cephalonica eggs $(\%)$ and $\mathrm{x}=$ time duration of 15 watt UV irradiation (Fig. 1 ).

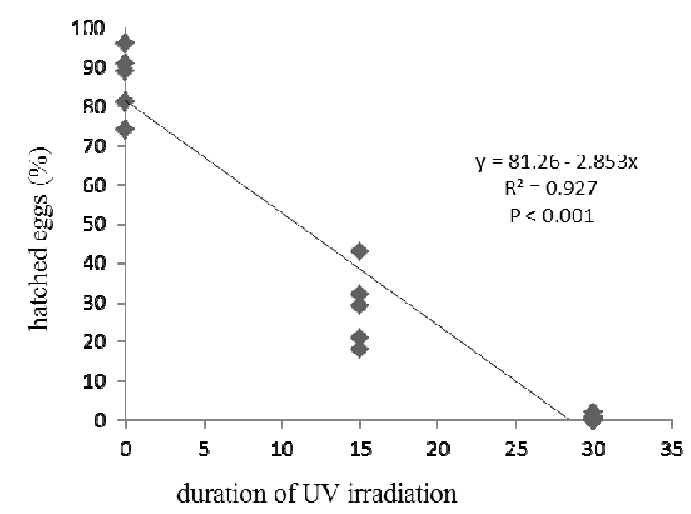

Fig.1. The relationship between the 15 watt ultraviolet radiation and hatching of $C$. cephalonica eggs

The model shows that hatched eggs proportion decrease linearly if duration of UV irradiation increase. In order to produce no hatched C. cephalonica, minimum 28.48 minutes of the 15 watt UV irradiation was needed. This is contrast with [24] shows that C. cephalonica eggs irradiated by 15 watts UV for 90 minutes still be able to hatch as much as $0.75 \%$. This difference is likely due to differences in equipment specifications which were used. Reference [14] did not explain how the distance between the UV lamp and
C. cephalonica eggs. In this study, the distance between the UV lamp and C. chepalonica eggs was $+15 \mathrm{~cm}$.

The model also indicates that $C$. cephalonica eggs could still hatch if being irradiated by 15 watt UV less than 28.48 minutes. The emerge larvae from $C$. cephalonica eggs used as factitious host for rearing parasitoid is very disturbing and will determine the success of parasitoid rearing. Emerge C. chepalonica larvae in parasitoid could eat and glue $C$. cephalonica eggs and parastoid in it, finally parasitoid died. Therefore, the supply of $C$. cephalonica eggs as factitious hosts must be treated by 15 watt UV at least 28.48 minutes at the distance between lamp and eggs is $\pm 15 \mathrm{~cm}$. For practical purpose, it is advised to use the 30 minutes duration of UV irradiation. This is in line with the [23] that shows there is not any hatching C. cephalonica eggs if it is iradiated by $15 \mathrm{UV}$ watts for 30 minutes. Therefore it is $15 \mathrm{UV}$ irradiation duration that shorter than 30 minutes is not good because most of the C. cephalonica eggs could still develop into larvae.

\section{B. Suitability of Corcyra cephalonica Eggs for Breeding Telenomus rowani, Trichogramma japonicum and Tetrastichus schoenobii}

The research shows that T. rowani, T. schoenobii could not be reared in C. cephalonica eggs. There was no C. cephalonica egg invested by $\mathrm{T}$. rowani and $\mathrm{T}$. schoenobii wasps that invested to $C$. cephalonica eggs in test tube. Appeared T. rowani and T. schoenobii wasps was not intrested to lay their eggs on C. cephalonica eggs, so no parasitized C. cephalonica eggs, and failed continue their descendants. This incontrast to $\mathrm{T}$. japonicum that could be reared on C. cephalonica eggs (Table 1).

\section{TABLE I}

CORCYRA CEPHALONICA EGGS SUITABILITY FOR BREEDING TELENOMUS ROWANI, TRICHOGRAMMA JAPONICUM AND TETRASTICHUS SCHOENOBII

\begin{tabular}{|c|c|c|c|c|c|}
\hline \multirow{2}{*}{$\begin{array}{l}\text { Para- } \\
\text { sitoid } \\
\text { Species }\end{array}$} & \multirow{2}{*}{$\begin{array}{c}\text { Sum of } \\
\text { Corcyra } \\
\text { cephalonica } \\
\text { eggs } \\
\text { treated(n) }\end{array}$} & \multirow{2}{*}{$\begin{array}{c}\text { Mean of } \\
\text { parasitized } \\
\text { eggs } \\
\text { (grains) }\end{array}$} & \multicolumn{2}{|c|}{$\begin{array}{c}\text { Mean of } \\
\text { off spring/betina }\end{array}$} & \multirow[t]{2}{*}{ Specification } \\
\hline & & & male & famele & \\
\hline$T r$ & 50 & 0 & - & - & Not compatible \\
\hline$T j$ & 50 & 23.4 & 4 & 16.4 & Compatible \\
\hline$T s$ & 50 & 0 & - & - & Not compatible \\
\hline
\end{tabular}

The result of the study reinforce reference [12] shows that the $T$. japonicum could be reared massely with factitious host. Reference [4] shows that T. schoenobii could be cultured only in Scirpophaga eggs. The effort of in vitro rearing of $T$. schoenobii as in [16] leads the use of $T$. schoenobii in RSB biological control. Reference [4] shows that given the socio-economic conditions of rice farmers in Indonesia in general, presumably habitat management efforts to support the development of T. schoenobii much more appropriate than application of parasitoid release. For this purpose, the $T$. schoenobii bioecology is absolutely necessary to be understood. 
Development of utilization of the three species of RSB parasitoid needs to be done continuously in various ways. Although $T$. rowani and $T$. schoenobii could not be reared on factitious hosts, increasing of the utilization of $T$. rowani and $T$. schoenobii might be done through conservation and captive breeding of RSB egg parasitoids to be released back to rice agro-ecosystem.

Conservation could be done by applying culture techniques of rice that might create a favorable environment for the development of the parasitoid. To maintain wild plants presence around the paddy crop as an alternative habitat and the parasitoid feed providers and to limit using pesticides minimally as few as posible are concrete actions that could be done to conservate the parasitoids.

Captive breeding of parasitoids might be done by collecting RSB eggs from the field. The RSB eggs collected is put in test tube and incubated in the laboratory until it develop to be RSB larvae or its parasitoids appear. The appearing RSB eggs parasitoid is released back out to the paddy agroecosystem, and the appearing RSB larvae are prevented to move from test tube to paddy crops by glue or gasolin or water, and than the larva died.

Another way for RSB eggs parasitoid captive breeding is by feeding (baiting) RSB egg parasitoids with $S$. incertulas eggs in the field and maintained in the laboratory. $S$. incertulas moths are caught from field (paddy crops). The $S$. incertulas moths colected are maintained individually in transparent plastic bottles. Pieces of fresh rice leaf put into the bottles for moths laying eggs. The eggs resulted are harvested every day by cutting the $4 \mathrm{~cm}$ long leaf where the eggs attached. The egg groups are used as RSB egg parasitoids bait. The RSB egg groups are attached on paddy leaf by using a stapler. Clumps of the paddy placed by the RSB egg are marked by plastic rope. After two days the eggs are taken back (harvested) by using scissors and put in a test tube and covered by a transparent colored tulle fabric. A test tube may contain one or several groups of eggs. Then the egg groups are incubated at $\pm 25^{\circ} \mathrm{C}$ in plant protection laboratory until they develop to be RSB larvae or its parasitoids appear. The emerge RSB egg parasitoids wasps are released back to the paddy agroecosystem, and the emerge RSB larvae are prevented to move from test tube to paddy crops by glue or gasoline or water, and than the larva died.

The use of $T$. japonicum, beside it can be done through the conservation and captitive breeding, it can also be done through inundation. Inundation should be done at hight levels $S$. incertulas population and low level $S$. incertulas eggs parasitization. Inundation must be supported by the parasitoid rearing ability massely. $T$. japonicum mass rearing can be done by using $C$. cephalonica egg $s$ as factitious host.

\section{Relationship between storage duration of C.cephalonica Eggs and emerged T. japonicum wasps.}

The relationship between storage duration of $C$. cephalonica egg irradiated by 15 watt UV for 30 minutes at $5{ }^{\circ} \mathrm{C}$ and emerged $T$. japonicum could be expressed by the equation of $\mathrm{y}=31.04-1.151 \mathrm{x}, \mathrm{R}=0.930, \mathrm{R}^{2}=0.865$, $\mathrm{P}=0.000$, where $\mathrm{y}=$ the number of emerged $T$. japonicum wasps, and $\mathrm{x}=$ dutation (days) (Fig. 2).

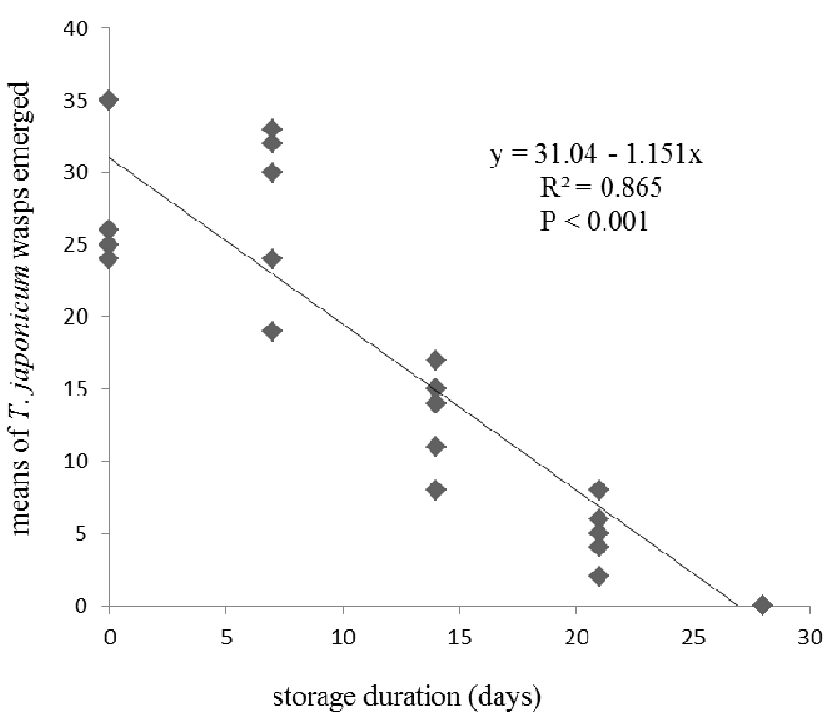

Fig.2. The relationship between storage duration of $C$. cephalonica egg irradiated by 15 watt $\mathrm{UV}$ for 30 minut at $5{ }^{\circ} \mathrm{C}$ and emerged $T$. japonicum

From the formula is known that the C. cephalonica eggs storege before being used as factitious host decreased theirs suitability for rearing T. japonicum. The model shows that the $\mathrm{C}$. cephalonica eggs storage before being used as factitious host for rearing $T$. japonicum must decrease the number of $\mathrm{T}$. japonicum wasps resulted. The number of emerged $T$. japonicum wasps decrease significantly if storage duration of $\mathrm{C}$. cephalonica eggs used as factitious host is increased sharply. If C. cephalonica eggs used as factitious host for rearing $\mathrm{T}$. japonicum was wich had been stored at $+5{ }^{\circ} \mathrm{C}$ for 26.97 days or more, there was not $\mathrm{T}$. japonicum wasps resulted. Reference [25] shows that C. cephalonica eggs before being used for breeding parasitoid could be stored in freezer but did not explain how storage duration could be done.

To determine how long duration C. cephalonica eggs storage must be done. It depends on how much maximum risk of failure may be incurred and the urgency of parasitoid rearing. The model indicats that if the acceptable maximum risk of C. cephalonica eggs storage duration is $50 \%$, the maximum $C$. cephalonica eggs storage duration able be done is 13.48 days.

\section{Parasitoid Storage}

After being stored in a refrigerator at a temperature of $5{ }^{\circ} \mathrm{C}$ for 6 weeks, T. japonicum pupae was still very good and did not interfere parasitoid development. The emerged $T$. japonicum wasps proportion from $T$. japonicum pupae stored for $1,2,3,4,5$ and 6 weeks were not different significantly than controls. The emerged $T$. japonicum wasps proportion from T. japonicum pupae stored for 7 weeks or more was decreased significanly than controls, event thougt the emerged $T$. japonicum wasps proportion was still reached 0.586 (Table 2). 
TABLE II

THE INFLUENCE OF TRICHOGRAMMA JAPONICUM PUPAE STORAGE DURATION AT 5 OC TO EMERGED TRICHOGRAMMA JAPONICUM WASPS

\begin{tabular}{|l|c|c|c|}
\hline $\begin{array}{l}\text { storage duration } \\
\text { at } 5{ }^{\circ} \mathrm{C} \text { (week) }\end{array}$ & $\begin{array}{c}\text { Total of } \\
\text { pupae } \\
\text { treated } \\
(\mathrm{n})\end{array}$ & $\begin{array}{c}\text { Means of emerged } \\
\text { Trichogramma } \\
\text { japonicum } \text { wasps } \\
\text { proportion }\end{array}$ & $\begin{array}{c}\text { Means of sex ratio } \\
\text { of male and } \\
\text { famale }\end{array}$ \\
\hline Tidak disimpan & 501 & $0.820 \mathrm{a}$ & $0.244 \mathrm{a}$ \\
1 & 579 & $0.818 \mathrm{a}$ & $0.288 \mathrm{a}$ \\
2 & 566 & $0.814 \mathrm{a}$ & $0.276 \mathrm{a}$ \\
3 & 564 & $0.798 \mathrm{ab}$ & $0.304 \mathrm{a}$ \\
4 & 573 & $0.770 \mathrm{ab}$ & $0.310 \mathrm{a}$ \\
5 & 570 & $0.764 \mathrm{ab}$ & $0.292 \mathrm{a}$ \\
6 & 574 & $0.738 \mathrm{abc}$ & $0.260 \mathrm{a}$ \\
7 & 600 & $0.694 \mathrm{bc}$ & $0.256 \mathrm{a}$ \\
8 & 583 & $0.648 \mathrm{~cd}$ & $0.310 \mathrm{a}$ \\
9 & 592 & $0.586 \mathrm{~d}$ & $0.324 \mathrm{a}$ \\
\hline
\end{tabular}

Means within a column followed by the same letter are not significantly different according to the Duncan's Multiple Rang Test.at $p \leq 0.05$ level.

In all treatments the $T$. japonicum wasps was emerged 13 days after parasitoid pias was removed from the refrigerator. Therefore parasitoid storage need the ensure of electricity supply to refrigerator life continuously. The $T$. japonicum pupae may develop into $T$. japonicum wasps in refrigator if storage temperature increase significantly that caused by electricity supply disconected. Therefore the results of the research could be an input for designing packaging equipment to take parasitoid to field so it would not develop into wasps on the way.

\section{CONCLUSION AND RECOMMENDATIONS}

\section{A. Conclusion}

Among the three species of egg parasitoids of $S$. incertulas found, only $T$. japonicum could be mass reared on eggs of $C$. cephalonica. C. cephalonica eggs irradiated by 15 watts ultraviolet at least 28.48 minutes at a distance between lamp and eggs $\pm 15 \mathrm{~cm}$ could suppress $C$. cephalonica eggs hacthing to be zero (no larvae emerged) Irradiated $C$. cephalonica eggs storage used as factitious host for $T$. japonicum mass rearing could supress emerged $T$. japonicum wasps. C. cephalonica eggs irradiated storage at $\pm 5{ }^{\circ} \mathrm{C}$ for 26.97 days or more may not be used as factitious host for $T$. japonicum mass rearing. $T$. japonicum pupae storaged for maximum 6 weeks at $5{ }^{\circ} \mathrm{C}$ did not reduce the number of emerged $T$. japonicum wasps, but number of emerged $T$. japonicum wasps reduced significantly if $T$. japonicum pupae storage duration was done for seven weeks or more. T. japonicum pupae storage did not influence significantly to sex ratio of emerged $T$. japonicum wasps.

\section{B. Recommendations}

The utilization of egg parasitoids for control of RSB are suggested to do the three techniques compatibly, consisting of conservation, captive breeding and inundation. In $T$. japonicum mass production, it is suggested to use $C$. cepalaonica eggs irradiated by 15 watt ultraviolet for 30 minutes at a distance beetween lamp and $C$. chepalaonica eggs $\pm 15 \mathrm{~cm}$ as factitious host. C. chepalaonica eggs used must be fresh, and do not use $C$. chepalaonica eggs stored in the refrigerator for some days. For the supply of $T$. japonicum stockes are advised to deposit $T$. japonicum pupae (parasitoid pias aged 6 days after the investment) in a sealed container in the refrigerator at a temperature of $5{ }^{\circ} \mathrm{C}$. In inundation, it is recommended to use parasitoid stockes stored no more than 6 weeks.

\section{ACKNOWLEDGMENT}

We would like to thank Direktorate General of Hight Education, Ministry of Education and Culture for funding competitive grant research based on agreement letter of advance research number 11/UN21.6/PL/2012 date 2012 February $15^{\text {th }}$.

\section{REFERENCES}

[1] M. Syam, Suparyono, Hermanto and D.S.Wuryandari, Masalah Lapang Hama Penyakit Hara pada Padi, 3th ed., Puslitbangtan, Bogor, 2007.

[2] S. S. Siwi, N. Ridha and E. Mahrub, "Identifikasi jenis penggerek batang padi genus Schirpophaga Treitschke (Lepidoptera: Pyralidae) dari daerah Indramayu dan Maros," pp 357-370, Prosiding Seminar Nasional Entomologi dalam Perubahan Lingkungan Sosial, Bogor, 5 Oktober 2004.

[3] Wilyus, "Pengendalian Hayati Penggerek Batang Padi dengan Pemanfaatan Parasitoid Telur dari berbagai Tipologi Lahan di Provinsi Jambi," Disertrasi PhD, Srywijaya Univeresity, Palembang, 2012.

[4] A. Rauf, "Parasitisasi telur penggerek batang padi putih. Scirpophaga innotata (Walker) (Lepidoptera: Piralidae): Saat terjadi ledakan di Kerawang pada awal 1990-an," Bul. Hama dan Penyakit Tumbuhan, vol. 12(1), pp. 1-10, 2000.

[5] H. Hamidi, D. Buchori, H. Triwidodo, "Keanekaragaman parasitoid dan parasitisasinya pada pada pertanaman padi di kawasan Taman Nasional Gunung Halimun," J. Hayati, vol. 10(3), pp. 85-90, 2003.

[6] A. Ardjanhar, S.S. Siwi, E. Mahrub, "Peranan parasitoid telur penggerek batang padi pada lahan yang diaplikasi insektisida kimia di daerah Indramayu," Prosiding Seminar Nasional Entomologi dalam Perubahan Lingkungan Sosial, pp. 371-384, Bogor, 5 Oktober 2004.

[7] M. Thamrin, S. Asikin, "Populasi serangga musuh alami pada lingkungan iklim mikro di lahan pasang surut," pp. 413-418, Prosiding Seminar Nasional Entomologi dalam Perubahan Lingkungan Sosial, Bogor, 5 Oktober 2004.

[8] M. Z. Hamijaya, M. Tamrin and S. Asikin, "Dominasi spesies parasitoid telur penggerek batang padi pada tipologi lahan basah di Kalimantan Selatan," pp. 467-474, Di dalam Prosiding Seminar Nasional Entomologi dalam Perubahan Lingkungan Sosial, Bogor, 5 Oktober 2004.

[9] K. Suneel, M.A. Khan, K. Arvind and S. Kuldeep. 2008. Biodiversity of natural enemies in paddy ecosystem and their seasonal dominance. Abstract. Annals of Plant Protection Sciences. [Online]. Available: http://www.indianjournals.com.

[10] Wilyus, "Survey eksplorasi parasitoid telur pengggerek batang padi di Desa Sungai Duren Kecamatan Jambi Luar Kota," 11p, Elektronik Journal Proseding Seminar Nasional BKS PTN Wilyah Indonesia Barat, Banten, 13 -15 April 2009.

[11] Wilyus, F. Nurdiansyah, S. Herlinda, C. Irsan \& Y. Pujiastuti, "Potensi parasitoid telur penggerek batang padi kuning Scirpophaga incertulas Walker pada beberapa tipologi lahan di Provinsi Jambi," $J$. HPT Tropika, vol. 12(1), pp. 56-63, 2012.

[12] L. Li, "Worldwide use of Trichogramma for biological control on different crops: A survey," Biological control with egg parasitoids, pp 37-53, In E. Wajnberg, S. A. Hassan (eds.). International Organization for Biological Control, UK, 1994.

[13] J. C. Brower, "Eggs of stored product Lepidoptera hosts for Trichogramma evenesens (Hym: Trichogramma and other eggs parasitoid," pp. 310, Int. Symp. San Antonio, Tx, USA, 23-27 Sept. 1990.

[14] H. Klomp and B. J. Teerink, "The elimination of super numerary larvae of the gregarious egg parasitoid Trichogramma embriophagam (Hym: Trichogramrnatidac) in egg of the host Ephestia kuchniella (Lep :Pyralidae)," Entomophaga, vol. 23(2), pp. $153-159,1978$ 
[15] I. W. Laba, A. Kartohardjono and D. Kilin, Pemanfaatan parasitoid Tetrastichus schoenobii Ferr. untuk mengendalikan penggerek batang padi putih. Scirpophaga innotata Walker, Peper was presented in seminar temu teknologi dan persiapan pemasyarakatan PHT, Subang, 16-19 Juni 1997.

[16] D. C. Ding, H. G. Qiu and C. B. Hwang, In vitro rearing of an egg parasitoid Tetrastichus schoenobii Ferriere (Hymenoptera: Tetrastichidae), Inst Entomol, Cntr Sanghai, vol 1, pp. 55-58, 1980.

[17] S. Herlinda, L. Daha and A. Rauf, Biologi dan pemanfaatan parasitoid telur. Trichogramma chilonis (Hymenoptera: Trichogrammatidae) untuk pengendalian Heliciverpa armigera (Lepidoptera: Noctuidae) pada pertanaman kedelai dan tomat. pp 23

32. Prosiding Seminar Peranan Entomologi dalam Pengendalian Hama Ramah Lingkungan dan Ekonomis, PEI Bekerjasama dengan Program Nasional PHT, Bogor, 16 Februari 1999.

[18] T. Djuwarso and E. A. Wikardi. Teknik perbanyakan Trichogramma spp di Laboratorium dan kemungkinan Penggunaannya, Jurnal Litbang Pertanian, vol. 18(4), pp. 111-119, 1999.

[19] S. Herlinda, Teknologi produksi massal dan pemanfaatan parasitoid telur hama sayuran, B17, pp. 1-9, Prosidung Seminar Nasional dalam Rangka Dies Fakultas Pertanian Universitas Sriwijaya dan Peringatan Hari Pangan Sedunia, Palembang, 7-8 Oktober, 2002.

[20] M. S, Pabbage, J. Tandiabang, Parasitisasi Trichogramma evanescens Westwood (Hymenoptera: Trichogrammatidae) pada berbagai tingkat populasi dan generasi biakan parasitoid terhadap telur penggerek batang jagung Ostrinia furnicalis Guenee, Agritrop vol. 26(1), pp. 41-50, 2007.
[21] S. Herlinda, A. Ekawati and Y. Pujiastuti, Pertumbuhan dan perkembangan Corcyra cephalonica (Stainton) (Lepidoptera: Pyralidae) pada media lokal: Pengawasan mutu inang pengganti, Agricultura, vol. 16 (3), pp. 153-159, 2005.

[22] U. Nurwahidah, M. S. Saenong, Pembiakan massal (mass rearing) ngengat beras (Corcyra cephalonica staint.) pada beberapa media, pp. 90-94, Prosiding Seminar Ilmiah dan Pertemuan Tahunan PEI dan PFI XVI Komda Sul-Sel, 2005.

[23] Marwoto, Perbanyakan telur Corcya chepalonica pada berbagai media untuk inang pembiakan massal parasitoid telur Trichogrammatoidea bactrae-bactrae Nagaraja, Penelitian Pertanian Tanaman Pangan, vol. 2(3), pp. 132-136, 2004.

[24] S. Herlinda, U. Amri and B. Hamid, Perbaikan kualitas pembiakan massal Trichogramma melalui penyinaran telur inang laboratorium Corcyra cephalonica (Stainton) dengan menggunakan ultraviolet. Majalah Sriwijaya, vol. 39(3), pp. 55-61, 2004.

[25] Surtikanti, Potensi parasitoid telur sebagai pengendali hama penggerek batang dan penggerek tongkol jagung Iptek Tanaman Pangan, vol. 2, pp. 192-203, 2006.

[26] S. Herlinda, A. Ekawati and Y. Pujiastuti, "Pertumbuhan dan perkembangan Corcyra cephalonica (Stainton) (Lepidoptera: Pyralidae) pada media lokal: Pengawasan mutu inang pengganti," Agricultura, vol. 16 (3), pp. 153-159, 2005 